\title{
Chapter 6 \\ Transformative Change Through Ecological Consumption and Production of Ancient Wheat Varieties in Tuscany, Italy
}

\author{
Guido Gualandi and D. Williams-Gualandi
}

\begin{abstract}
In the 2016 Volume 2 of the Satoyama Initiative Thematic Review (SITR), a summary of the activities of the Grani Antichi Association in Montespertoli, Tuscany, was introduced with a roll out plan for transformative change of the supply chain and possible replication of the project in other regions. The main goal of the project has been to restore and preserve ancient varieties of wheat, cultivate them sustainably and include a form of payment for the least compensated members of the production chain. The aims of the Association are to reduce the carbon footprint of modern agricultural practices and the landslides and soil erosion caused by them, to preserve biodiversity and most importantly, to improve farmers' revenue, enabling them to safeguard the environment and improve health by cultivating healthy food. The preservation of social ties and local knowledge is an additional result. Markers of the project's success include benefits that are equally distributed across the production chain, farmers who are motivated to cultivate ancient wheat varieties and the conversion of 500 ha of abandoned or conventionally cultivated land to a more sustainable and biodiverse system. The market economy system in place was dismantled, and farmers now have access to more economic benefits, which must be distributed fairly. Because the project provides a transformative model of production and consumption outside the traditional market economy system, it appears to function with a complete multi-sectoral chain, where producers, food processors and consumers agree on a set price for a defined product. This chapter provides a preliminary analysis of the successes and challenges related to the main project and to upscaling in different areas.
\end{abstract}

Keywords Grain · Biodiversity · Sustainable farming · Scale up · Farmers' cooperative

\footnotetext{
G. Gualandi (ه)

Associazione Grani Antichi di Montespertoli, Tuscany, Italy

e-mail: guido@guidogualandi.com

D. Williams-Gualandi

NHL Stenden University of Applied Sciences, Leeuwarden, Netherlands

e-mail: debra.williams.gualandi@nhlstenden.com
} 


\subsection{Introduction}

Biodiversity loss triggered by modern agriculture is a serious concern for local governments, research centres, producers and consumers the world over. In Italy, some regional governments have sponsored activities involving local flora and traditional foods, including the preservation of edible plants. The region of Tuscany has been particularly active in preserving a number of crop and livestock varieties to ensure the continuation of specific species. It is known that some older and more resilient plant varieties are more adaptive to climate change impacts, such as higher temperatures and the less rainfall, as well as soil erosion. For this reason, these varieties are considered socially and environmentally beneficial. However, the trend to encourage cultivation of older grain varieties has been slow to develop because grain revenues are very low and governments do not provide incentives to grain farmers. This chapter focuses on a project involving wheat.

In the specific case of wheat (Triticum), the process of selection and hybridisation, which has taken place over a span of more than 10,000 years, resulted in an abundance of wheat varieties throughout the world. Each variety adapted to the growing conditions of its local environment. However, genetic engineering and the processes of agricultural industrialisation have radically decreased wheat genotypes. Until quite recently, farmers could only choose from a few modern varieties available for purchase. As the national registry for plant species did not include ancient varieties, it had become more and more difficult to cultivate those varieties legally. Although modern varieties are attractive for their high yield, they require the use of fungicides, pesticides and fertilisers, all of which compromise the health of the ecosystem. Local ancient varieties offer many potential benefits as they are healthier for human consumption, more sustainable and adaptable to their environment and require no fertilisation or treatments. However, local communities have lost the specific know-how to cultivate ancient wheat varieties. In addition, reproducing these varieties is often costly due to lower yield, particularly for small farms.

Most of the interventions named in Chap. 1 were needed for the success of this project, mainly incentives and capacity-building and cross-sectoral cooperation, with the most important leverage points being: visions of a good life; values and action; justice and inclusion in conservation; and education, knowledge generation and sharing.

Facing these challenges, this chapter discusses how a project run by a farmers' cooperative, the Grani Antichi Association (Ancient Grains Association), could bring about the seeds of transformative change based on the following: (1) maintaining a reasonable final cost for consumers; (2) raising consumers' awareness of the multiple benefits of local varieties; and (3) introduction of a sustainable producer-consumer cycle. 


\subsection{Background}

\subsubsection{Project Area: Montespertoli}

The town of Montespertoli is located in the Florence metropolitan administrative area, in the region of Tuscany, at a distance of approximately $32 \mathrm{~km}$ south/southwest of the city (Table 6.1). The territory covers an area of approximately $120 \mathrm{~km}^{2}$, and is crossed by the Elsa and Pesa rivers. The predominantly hilly terrain, made up almost entirely of sharp ridges and valleys with an average elevation between $200 \mathrm{~m}$ and $422 \mathrm{~m}$, contributes to the fact that Montespertoli is less densely populated than neighbouring towns, which are located in flatter areas.

According to the 1871 census, there were 9135 inhabitants in Montespertoli, and today the population has increased to 13,500 . Inhabitants are spread throughout the territory, an atypical situation compared to neighbouring towns where the population tends to gravitate to the town centre. The 1871 census reported that 38 families owned land in Montespertoli. Most of these families lived in Florence and sold farm products such as wheat, oil, wine and cattle. In 1871, 122 individuals served as public clerks, or in ecclesiastical or administrative positions, while the remainder of the population worked the land. Until the Italian economic boom of the 1960s, farming remained the primary activity in Montespertoli, with the addition of strawhat production that employed approximately 1000 people, primarily women.

Over the last four decades, due to changes in external market conditions, industrial food production and mechanisation of farming techniques, a significant shift in land use has taken place, with a sharp increase in vineyards and wine production $\left(22 \mathrm{~km}^{2}\right)$, a sharp decrease in land used for wheat production and the disappearance of cattle altogether. The higher cost of cultivating wheat in Montespertoli compared to wheat produced on flat terrain forced this transformation. This change also led to a shift in the social fabric, away from agricultural activities (including town fairs, harvest festivals, etc.), with a decrease in farmers and an increase in individuals who commute to the cities of Florence or Empoli for work.

Table 6.1 Basic information of the case study area

\begin{tabular}{l|l}
\hline Country & Italy \\
\hline Region & Toscana \\
\hline District & Florence \\
\hline Municipality & Montespertoli \\
\hline Size of geographical area (hectare) & 12,000 \\
\hline Number of indirect beneficiaries & 13,474 \\
\hline Dominant ethnicity(ies), if appropriate & n.a. \\
\hline Size of case study/project area (hectare) & 12,000 \\
\hline Number of direct beneficiaries & n.a. \\
\hline Dominant ethnicity in the project area & n.a. \\
\hline Geographic coordinates (latitude, longitude) & $43^{\circ} 39^{\prime} 30.60^{\prime \prime} \mathrm{N} ; 11^{\circ} 3^{\prime} 32.36^{\prime \prime} \mathrm{E}$ \\
\hline
\end{tabular}


In Montespertoli there was a small SEPLS of wheat producers who sold their wheat to the only mill remaining in the area. In the past 50 years, all wheat production was converted from local grain varieties to just a couple of international varieties. However, as prices decreased, the SEPLS entered into a crisis as farmers could not earn sufficient funds to support their livelihoods. Under such circumstances, 6 years ago a project was introduced, aiming to reintroduce local varieties with higher revenues per kilogram to help farmers economically.

In this context, the gradual reintroduction of wheat production in Montespertoli starting in 2010 also contributed to the reintroduction of cattle and other animals in the area due to the rotation of wheat with foraging crops. At present, three cattle farmers are using 150 ha of pasture each, with one small local cheese production (Marzolino di Lucardo cheese) just beginning. As fields are used once again, more crops are being cultivated and more wild varieties can colonise the fields as no herbicide is used.

\subsubsection{Project Activities}

The key activities of this project include: (1) founding of an association, making it possible to incorporate cross-sectoral cooperation between universities, city councils, private companies, traders and farmers; (2) creating a new economic model with incentives and capacity building; and (3) replication and dissemination of the project with pre-emptive action. These activities were made possible by embracing a different vision of good life and ensuring environmentally friendly technology, innovation and investments through promotion of education and knowledge generation and sharing.

\subsection{Founding of the Grani Antichi Association}

\subsubsection{Scope of the Association}

As a response to local changes in wheat production in the Montespertoli area, the Grani Antichi Association project, which started in 2014, sponsors and verifies practices in relation to sustainable agriculture to increase the biodiversity of wheat, as well as other local flora and fauna. All members pay an annual fee to finance the activities and run the Association. The region and city council have also financed specific projects with ad hoc grants. The initiative is characterised by multi-sectoral cooperation among researchers from the University of Florence, members of the Montespertoli city council, millers, bakers, consumers, and farmers, who cultivate ancient and biodiverse varieties of wheat, such as Andriolo, Inallettabile, Sieve, Frassineto, Autonomia B, Verna, Gentil Rosso, Farro Monococco and Dicocco. These wheat varieties are grown, milled and processed locally. Some of these 
varieties would have disappeared without the activities of the Association, as they were no longer being cultivated. The Association is now the official custodian of several varieties. This means that they were replicated in members' fields, with a state inspector verifying that the replication process is done according to set rules. Each ancient variety was tested in a different environment and best practices were shared with farmers by the Association's technicians so that they did not plant the wrong type for their soil. The Association has also introduced other cultivation such as rye, hemp, chickpeas, fava beans and other traditional rotation crops. These ancient crops are taller, do not need fertilisers and are more resilient. However, they produce less and can be affected by some different pathogens that farmers need to be aware of (Fig. 6.1).

\subsubsection{Patented Trademark}

The Grani Antichi Association recognises and protects growers and processors (i.e. millers, bakers, and pasta makers) with a patented trademark. A specific logo serves as a guarantee that the bread, pasta and flour carrying that logo are made respecting the Association's guidelines. For this purpose, a Participatory Guarantee System (PGS) has been created. PGS is a locally-focused quality assurance system and formalises the adoption of the Association's guidelines for cultivation and processing of wheat products. It certifies wheat producers and processors based on the active participation of stakeholders (producers grow grains, processors mill and process them by cooking or other means, and consumers eat them) and is built on a foundation of trust, social networks and knowledge exchange. In the Association's case, an annual inspection of all members is conducted by a voluntary group of stakeholders (more on https://www.ifoam.bio/).

\subsubsection{Wheat Product Analysis and Guarantee}

The Grani Antichi Association, in cooperation with the University of Florence, randomly and selectively tests the wheat for any mould, toxins or pesticides. Any portion of the wheat that appears unhealthy due to the presence of diseases or anomalies is tested and discarded if necessary. A pathologist from the University of Florence also checks the wheat for pathogens in the field before harvesting. At any moment, consumers can visit the processors and verify their operations. In 2019, many small billboards were created to indicate to passersby which wheat fields were planted with ancient grains from the Association.

These measures increase trust between the Association and its producers. The notion of trust is understood as a belief in the integrity of the product and the process leading to the product, as well as the commitment of all stakeholders to the principles of the Association. A high degree of acceptability of the principles and philosophy 


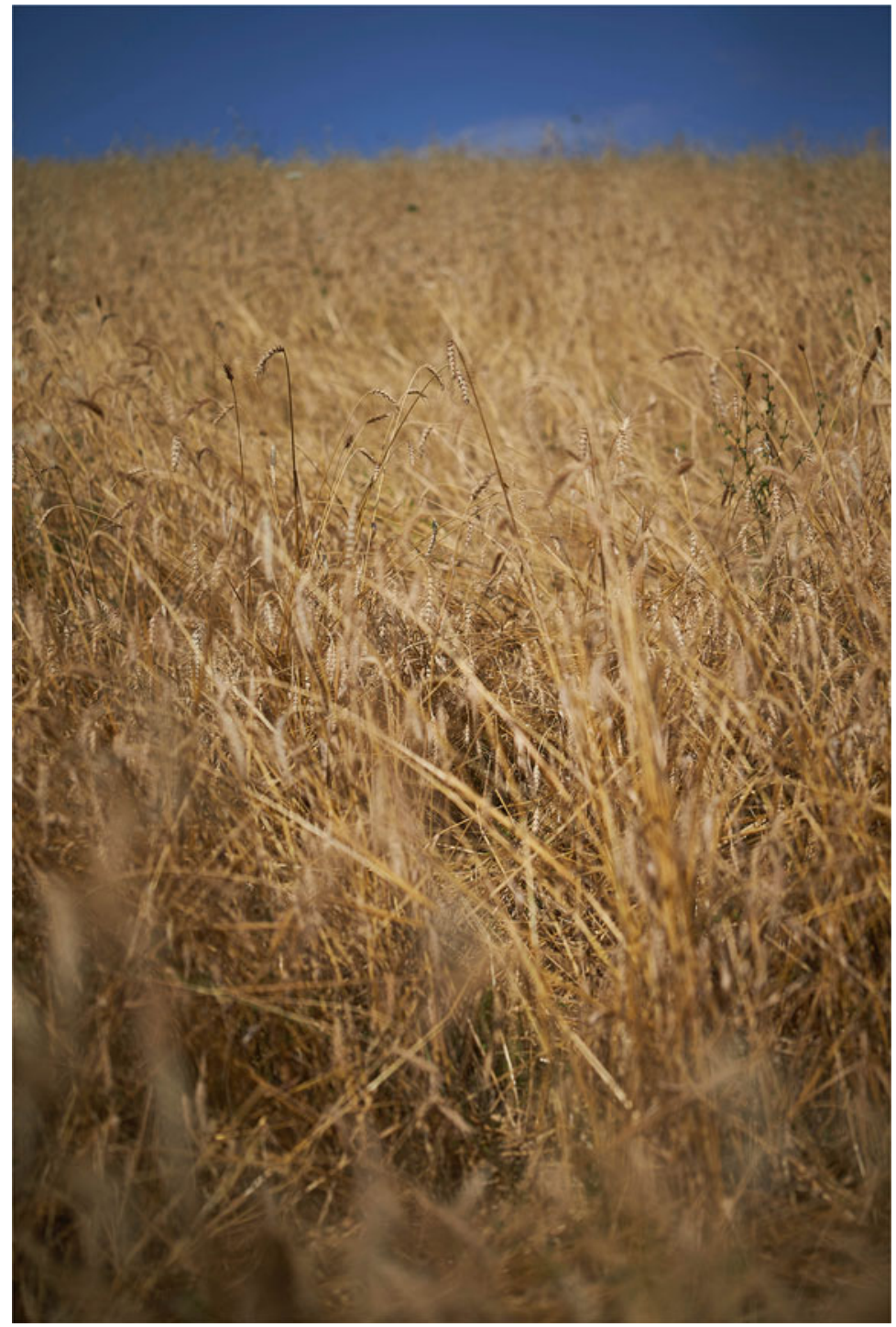

Fig. 6.1 Wheat field, Photo: Batistelli

of the Association amongst the various stakeholders is a fundamental factor in the project's success. 


\subsubsection{Grant and Funding for Farmers}

If in the earlier phase of the Association, relations between the Association and stakeholders were based on trust, a more explicit and defined system of relationships has been developed in the current phase. Thanks to a grant of 619,273 EUR from the regional government (Regione Toscana) and a mutual 5-year commitment to the continuation of the project, ten members of the Grani Antichi Association were selected to contribute to developing the chain from producer to processor. The members have invested in machinery (specifically tractors) and in the establishment of a certified seed factory. One of the Association's members invested in the creation of a certified seed operation thanks to initial funding from this grant. Farmers can now provide seed samples, which will be cleaned with modern machines, stored and certified according to norms controlled by government specialists.

At the same time, the Association has invested in registering wheat varieties which do not currently appear in the national registry, in order to be able to sell them legally. Over the next 2 years, most varieties will be successfully registered. Many were cancelled from the national register when they were no longer traded. Once this registration process is complete and the seed company fully operational, the farmers will be able to buy and sell the ancient varieties with their specifically registered names, and no longer under the vague nomenclature of 'wheat'. This in turn means that the labelling system of the final products will report the specific wheat variety, increasing their commercial value and legally recognisable identity.

\subsubsection{Education and Promotion}

The Grani Antichi Association promotes the organic and sustainable cultivation of wheat based on the belief that it is better for the environment and healthier for consumers. Members of the Grani Antichi Association have focused their activities on speaking and writing about the benefits of ancient grains for consumers, farming best practices and the economic implications of the project model. Conferences, participation in food markets, lessons in schools, universities and town halls are frequently carried out. Activities have also included lobbying with members of the public sector.

In partnership with the University of Florence, conferences have been held at medical centres with the aim of disseminating results of the latest research on ancient grains, which illustrates the health benefits of using ancient grains over commonlyused modern wheat varieties (e.g. Sofi et al. 2010). A recent conference at the University of Florence had the positive result of convincing one agronomist in Southern Tuscany that starting a project in his area to convert intensive agricultural operations to sustainable cultivation of ancient grains was viable. After learning about the ancient grains project, this individual then lobbied his own local city council to sponsor a project in his area. 
The Grani Antichi Association has also organised lectures and events in different city councils, mostly at the invitation of council members. Councils looking for solutions to improve local agricultural problems, convert abandoned areas, or improve local agricultural production have contacted the Association with invitations to illustrate that cultivating ancient grain wheat varieties in a sustainable and organic way is possible and economically viable. Resistance to the idea exists, especially after decades of conventional agriculture, so the Association uses data and testimonials to demonstrate the viability of projects of this sort on many levels.

\subsubsection{Challenges}

The survival of the Grani Antichi Association depends on the trust that has been created among its members, and between members and the local community. Most farmers tend to distrust food processors and large mechanised farmers. That is why it is important for all stakeholders to share a consensus on the principles and objectives of the Association. So far, the miller involved in the Montespertoli project has experienced an upswing in business. The environment prior to the project was challenging due to large mills gaining a greater share of business at lower prices. More than half of the miller's business now involves ancient grains. The three bakers involved have also increased their business by $10 \%, 20 \%$ and $100 \%$ respectively in three years. Similarly, the pasta makers and other farmers who sell ancient grains directly have increased their business and created new opportunities. One former member of the Association created a new agro-company which deals only with ancient grains, replicating the whole chain of production. Many people have been hired as a result of the project, and several businesses that had not been doing well are now thriving. During the COVID-19 lockdown, most of the farmers and processors selling ancient grain products sold the same amount or more products (some as much as double). Overall, they have become more resilient. Ancient grain clients generally buy regularly. The city council and many food processors are also using the ancient grain logo in their communication to gain prestige as, locally, it has been recognised as an added value. The Association is currently discussing the extent to which members are allowed use the logo in promoting their activities. Results have not yet been disclosed.

One of the main challenges the Association has faced has been how to keep the operation to a manageable size. In 2019, the Association defined and maintained a maximum of 10 wheat-producing hectares per farmer member per year. This allowed for the total number of members to increase, without increasing the total wheat production of the area. Without a maximum, a small number of large landowners could have produced a significant percentage of the overall wheat production, excluding newer, smaller farmer members from the Association. However, the Association had to manage the discontent of those farmers with larger potential production maximums. This contrasts with other models where the tendency is for a small number of large producers to emerge as the main stakeholders and 
decision-makers. The priority of community participation was valued over individual margins for growth. In addition, the Association has had to take into account the limited number of processors and limits to the client base in balancing the demand for wheat and the size of the production chain. Accordingly, the Association decided not to increase the total production of wheat volume per year, but rather to support replication of the project, both in proximity and in locations further afield. Some of the conditions for, and considerations involved in, the process of scale-up are considered below.

Another challenge concerns the duties and rules of food processors. Several documents and guidelines are shared by food processors who prefer loose rules and business friendly guidelines. Their product lines made with ancient grains are limited due to rigid protocols. So far, the Association has refused to open up to bigger companies that would increase the demand for ancients, but would also want more freedom. This is a limitation to the growth of ancient grain cultivation within the Montespertoli project, and it is not likely to change soon.

\subsection{Creating a New Economic Model}

One of the most important issues, if not the most important, for the successful implementation of a model, such as the one used by the Grani Antichi Association, is the economic implication. Looking at the activity of the Grani Antichi Association, it is clear that the market economy model does not fit a socio-economically sustainable grain system. Farmers have fixed costs and high risks, and fluctuating prices rarely correspond to these costs. In most of the systems involving ancient grains in Tuscany, prices of products along the supply chain are set either by the initiator of the project or with the help of the University of Florence. Five of these models, including the Montespertoli ancient grains, have already been studied and analysed (Sacchi et al. 2019). In this section, we will illustrate the Montespertoli case.

\subsubsection{The Market Economy Model}

While demand and supply have traditionally influenced wheat prices, climatic conditions and crude oil prices are now two important factors affecting wheat production. As stated by Enghiad et al. (2017), "Oil prices influence the cost of inputs for wheat production, and similar patterns observed in wheat and oil price fluctuations indicate high correlation between the two". Montespertoli farmers believe that a market economy model, where global supply and demand determine price, is not a viable model in many areas of Italy, where costs are higher than in other nations due to historical and geographical specificities (i.e. small, separate farms lots, and hilly terrain). 


\subsubsection{Possible Models}

Apart from the standard market economy model, where farmers try to sell to anybody they can for the best possible price at a given time, several other models exist. In Tuscany, some farmers belong to a consortium, where the consortium determines annual wheat prices and annual quantities for a group of farmers based on the consortium's ability to sell the wheat to distribution systems. Prices are set according to market demand, but farmers have some level of protection as at least annual prices and quantities are respected. Some other models involve a company or farm which subcontracts production to other farms. Figure 6.2 shows the different models that were studied by Sacchi et al. (2019).

Normally, a farmer sells wheat to a miller who then transforms it into flour and sells it to bakers. Bread is usually sold by bakers to shops or directly to consumers. In Tuscany, supermarkets sell mainly industrial bread and local bakeries sell mainly artisanal bread near residential areas. The graphic in Fig. 6.2 shows the share at different stages of the premium of bread, in EUR per kg. Montespertoli redistributes benefits more equally and maintains a reasonable pricing. The other chains are different Tuscan producer-consumer chains from the more industrial (lower price) to artisanal (high price). Sacchi et al. (2019, pp. 5-6) report,

While B1, B3, and B4 redistribute a relevant part of the premium over conventional bread to farmers, B2 and B5 mainly favour the final stages of the production chain. In B2, the gap between the purchase price of the flour by bakers and the final selling price of the bread is much wider, allowing bakers and retailers, such as large-scale distribution networks, to obtain a higher gross margin and quota of participation in the premium. The B5 chain, in

Fig. 6.2 Benefit

distribution of bread revenue in different chains in Tuscany in EUR per $\mathrm{kg}$ (Sacchi et al. 2019). Note. Figures for Montespertoli are shown in Chain B3. The other chains are industrial, supermarket and artisanal

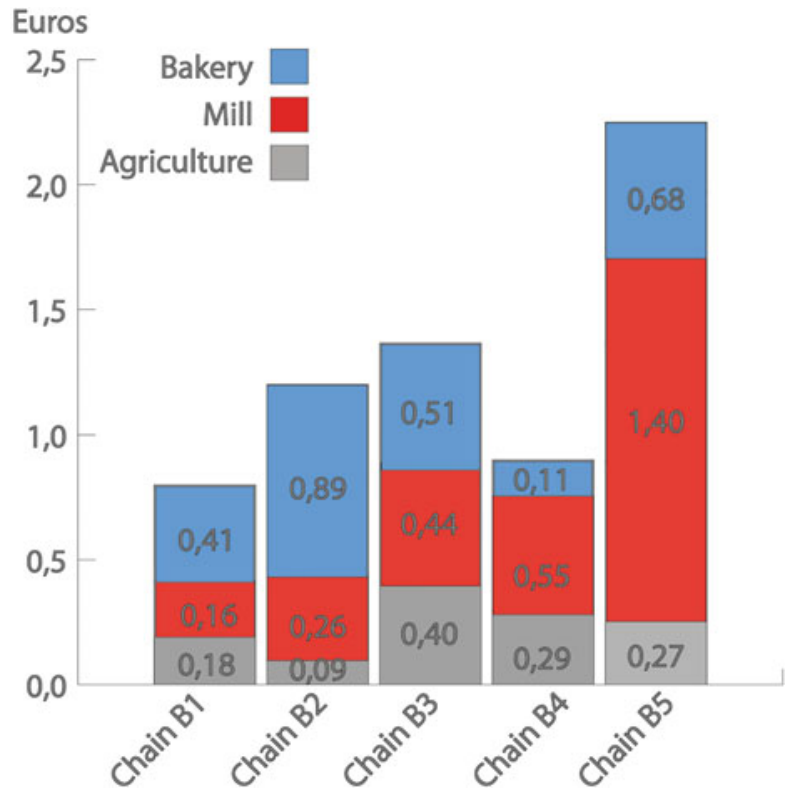


Table 6.2 Targets and indicators for the Montespertoli SEPL

\begin{tabular}{l|l|l}
\hline Indicator & 2013 & 2019 \\
\hline Montespertoli certified grains harvested & $1000 \mathrm{~kg}$ & $300,000 \mathrm{~kg}$ \\
\hline Ancient grains harvested & $\mathrm{n} / \mathrm{a}$ & $250,000 \mathrm{~kg}$ \\
\hline Wheat varieties cultivated & 4 & 28 \\
\hline Farmers involved & 3 & 45 \\
\hline Ha cultivated & 10 & 500 \\
\hline
\end{tabular}

Table 6.3 Amount of ancient grains farmed and milled and number of wheat varieties increased in Italy

\begin{tabular}{l|l|l}
\hline Indicator & 2013 & 2019 \\
\hline Ancient grains harvested & $\mathrm{n} / \mathrm{a}$ & $500,000 \mathrm{~kg}$ \\
\hline Wheat varieties cultivated & 5 & 50 \\
\hline Farmers involved & 10 & 100 \\
\hline Hectares cultivated & 200 & 1,000 \\
\hline Communes involved & 2 & 15 \\
\hline
\end{tabular}

contrast, favours the milling stage in particular. As far as the distribution of the price premium is concerned, B3 is the chain with the most equitable distribution (...).

An example of a very small-scale model is a farmer that cultivates the product, transforms the product and sells it directly to consumers. Even though this is possible, it requires an array of different types of knowledge, the right range of equipment and the involvement of several people. Not many farmers can achieve this model. In Montespertoli, a few farmers (3) have chosen to work this way, using the Association brand name. They are producing, processing and selling in local markets to a small and faithful consumer base, on their own.

In other cases, sometimes overlapping with the above-mentioned examples, community farming associations or consumer associations have managed to skip middlemen or shops. In those cases, there has been an increase in farmers' average selling price (ASP). However, these systems seem to have plateaued and usually represent a small niche in consumer buying patterns. In the area of Montespertoli, individuals generally purchase their bread and pasta at a shop or local supermarket, which requires products to be delivered to these locations.

Table 6.2 shows partial indicators for ancient grains SEPLs in Montespertoli. In Italy, there are many more hectares today (more than 10,000), but data is not available as ancient varieties were not accounted for as they were not in the national registry in 2013.

Table 6.3 shows partial indicators for ancient grains SEPLs in Italy, from projects directly sponsored by the Grani Antichi association from Montespertoli. 


\subsubsection{Fixed Price of Wheat}

Addressing the question of how to guarantee that farmers' costs are covered while also maintaining a market price that is attractive for shops and consumers, can be considered the Grani Antichi Association's most innovative achievement. The Grani Antichi Association first established a minimum revenue per hectare that would allow farmers to cover costs and earn a small amount. From this cost base, the price of bread was determined so that both millers and bakers would make a profit. To ensure that the product was within the purchase range of many people, rather than merely a wealthy elite, the final part of the chain is not allowed to raise the price more than a certain amount to guarantee the affordability of the product for most people. In this way, a fair distribution of profit was reached with approximately a third of the total price given to the producer, a third to the processor and a third to the shop (Fig. 6.2).

\subsection{Replication in Other Settings}

\subsubsection{Implementation Research}

Implementation research looks at how to strengthen systems using the experiences of stakeholders (decision-makers and implementers), while taking into account local context, priorities, and the complexity of the systems. Implementation research addresses an array of issues, such as acceptability, adoption, appropriateness, feasibility, fidelity, implementation cost, and sustainability, and is meant to address the 'know-do' gap.

In the case of the Grani Antichi Association project, and subsequent replications of similar projects in different Italian contexts, initial research into factors that have affected the success of the initial project (above), and have emerged as significant in other contexts at the outset is presented. Given the very recent developments beyond the first project, observations are of a preliminary nature, and require further research as each project grows over time. The Association has played an active role in encouraging farmers to replicate a similar system in other settings as an alternative to industrial wheat production.

\subsubsection{Initial Observations of a Modest Scale-Up}

We have considered the categories of acceptability, adoption and sustainability in our preliminary analysis. Acceptability refers to the community's belief in the principles of production and consumption outlined above. This includes various stakeholders: farmers, millers, processors and consumers. Adoption includes 
adherence to the growing guidelines (i.e. crop rotation, elimination of fertilisers, public information, control visits, etc.). Finally, sustainability includes factors that relate to the viability of the project over time from the perspective of each stakeholder. Qualitative data was collected through interviews conducted during the period from February to November 2019.

\subsubsection{Implementation in the Umbria Region}

A local Slow Food group learned of the Montespertoli experience and acted as a facilitator in creating a new group in the Umbria region. The group visited the Association in Montespertoli and obtained seeds and initial know-how to grow them and mill the wheat. In terms of acceptability, because the Slow Food group members already shared the Slow Food principles of 'good, clean and fair', acceptance of ancient grains and the economic model of $30 \%$ for each part of the chain did not meet with resistance. This initial adoption, even if it is small in volume in terms of surface area converted and grain output, could be significant in terms of visibility as it is implemented by a Slow Food group. If successful, it could serve as example for other farmers in the area.

In terms of adoption, a single farmer adhered to ancient grain growing methods, and supplied all of the wheat for one miller, who purchased it at a pre-set price, and processed the wheat for the Slow Food community. The market demand was defined by the pre-existing community, and the farmer and miller adhered to that quantity. A preliminary analysis views sustainability as relying on a continued and steady demand that does not exceed the farmer's land use and annual production. (size: 2 farmers, 10 ha)

\subsubsection{Implementation in Pavia}

In Pavia, two farmers who had lived in Montespertoli acted as a lever for the farming community there. In the hills of Pavia (Oltrepo Pavese), unlike other nearby areas with prestigious wine denominations which lead to growth in vineyard cultivation, no lucrative agricultural activity existed. It was therefore easier to convince a group of farmers to convert to ancient grains cultivation.

Adoption of the project included seven farmers, two millers and a number of bakers who undertook a radical change in their practice. Unlike the Umbria group, the Pavia group did not initially include consumers. Market demand needed to be created through local community education.

Therefore, in terms of acceptability, the initial farmers and processors involved believed in the viability of the project based on the principles of improving the quality of the wheat, increasing biodiversity and introducing sustainable practices. They did not, however, have a guarantee that the community would show the same level of acceptance. Sustainability would depend on the consumer demand that supports the production on the seven farms. 
After their first year of production, the entire yield was not sold. However, another miller from Val di Susa, in the Piedmont region, purchased the excess wheat and intends to begin his own project in his local area. (12 farmers, 20 ha)

\subsubsection{Implementation in Castelfranco di Sotto (Pisa Area)}

The mayor of Castelfranco invited the authors to hold a conference with the farming community in an aim to introduce sustainable practices and convert an economically depressed, conventional agricultural area into an organic farming district with biodiverse and healthier crops.

A large part of the land was owned by four farmers who were initially skeptical about the guidelines for cultivation of ancient grains, as well as the viability of the entire project which is based on selling wheat at higher prices than conventional wheat. The mayor and the vice-president of a local food association (Centro Commerciale Naturale) decided to focus specifically on the farmer with the largest farm, who was also considered a trend-setter in the community. After attending the conference, meeting with members of the Association and learning about how the project was implemented, the farmer was willing to try. The other farmers will wait to see the results of the trial. According to the local association, if the lead farmer decides that the project is viable, the others will follow.

\subsubsection{Implementation in Sansepolcro}

After a workshop about sustainable and organic agriculture (AIDA: ASSOCIAZIONE ITALIANA DI AGROECOLOGIA, or Agro-ecology for Organic Agriculture, University of Florence, 15 November 2019) held by the authors, an agriculture consultant decided to propose a workshop in Sansepolcro with local farmers. The mayor hosted and encouraged farmers to participate. A meeting followed, and several farmers were convinced by Montespertoli members. These farmers had been mainly cultivating tobacco as a cash crop and had very low margins. They decided to make a change and introduce more sustainable and organic practices which would benefit the local community; however, given that no bread or flour chain existed, the farmers decided to begin by producing wheat for pasta only.

Similar to the Pavia example, in terms of acceptability, the farmers involved believed in the viability of the project based on the principles of improving the quality of the wheat, increasing biodiversity and introducing sustainable practices. Sustainability will depend on consumer demand and acceptance of the principles of the project (several farmers involved). 


\subsection{Discussion: Transformative Change Starting from the Grain Farmer's Association}

The redistribution of economic benefits in the context of the Grani Antichi Association's activities has altered the production and transformation chain with beneficial effects on the ecosystem, as well as a redistribution of money. This has created positive outcomes as well as tensions in the group benefitting from the change. After the work of the founding members, who were primarily motivated by commitment to sustainability and biodiversity, farmers in Montespertoli and in the other areas took up the practice mainly because there is a fair distribution of the economic benefits (Fig. 6.2). It is clear that economic motivation is key in most cases for farmers. For politicians, however, support and consensus are very important.

The Association continued to grow in number of farmers until the mill reached full capacity. Now the production has hit a plateau and aspiring members have been encouraged to start an association of their own, which has happened in many cases (see below and Table 6.3). As new associations are being created, indicators for Italy are growing, while Montespertoli's remain stable.

\subsubsection{Consumers As Co-producers}

Normally, supermarkets have purchasing managers who search for products at the lowest prices. Producers are therefore pushed to have low prices and try to adapt by selecting providers of agricultural products at the lowest price in turn. For other products, especially niche ones, rarity or brand name can permit the reseller to have higher prices. In terms of wheat, ancient grain wheat and organic wheat are seen as more valuable as they constitute a healthier and more sustainable option, and are therefore sold at higher prices. However, that high price is not always transferred back to the producer. As the ancient grain chain in Montespertoli fixes prices for processors and resellers, the benefits are equally distributed (one third respectively to producers, processors and resellers). In this scenario, the end users (the consumers) are involved in checking the chain via the PGS and feel they are part of the chain as they are informed about the relationship between production and costs.

\subsubsection{A Leap of Faith}

When consumers are considered part of the chain, they need to trust that the organisation and the farmers are not trying to take advantage of them through pricing. As mentioned above, building trust is an important aspect of the Association's experience. The action of identifying each field with a metal sign with the name of producer, type of wheat planted and rotation crops is one example of this. 
Regularly planned community meals occur where people can participate and meet the producers. Every year a harvest celebration is another occasion to meet the producers and taste the products. Meetings and assemblies are always open to the public and advertised locally.

\subsubsection{Lessons Learned in Montespertoli}

One significant lesson learned in the past 2 years is that overproduction is more destabilising than wheat shortages. If there is a shortage, demand for products increases. Farmers sell the entirety of their product, and though they might not make the whole amount projected because of the shortage of wheat, they accept it. On the contrary, if farmers produce more wheat than expected, they saturate the market, but the price for wheat cannot decrease because it is set. The processors cannot therefore purchase all the wheat harvested in that given year, and projected purchasing agreements are compromised.

In 2019, the wheat yield was 50\% more than projected. Accordingly, the Association improved its quota system by putting a limit on both the hectare and the total number of kilograms per producer. Previously, the quota was based on hectares only. The quota system was proposed by the board of directors and voted on by members. In 2020, after a suggestion from the board, the farmers decided to assign the same quota to everyone regardless of any factor, such as small or large farms, founding or most recent members: they all cultivate three hectares and sell at the set high price of 4.5 tons of wheat. After a process of discussions, this emerged as the fairest choice. It was possibly the biggest adaptation of the project. It remains possible to exchange this right to sell between farmers at their convenience. This egalitarian choice has not been replicated in other projects so far. Overproduction in other areas has been solved primarily by lowering prices, similar to market economy mechanisms.

After many years of trials, farmers also learned that production can be abundant even without fertilisers or chemical products. Converting abandoned fields or industrially farmed fields to ancient varieties has improved water management (by digging ditches), landslide control (by planning crops that contain erosion), and production sustainability (fertile soil without chemicals).

\subsubsection{Scale-Up of the Project}

Acceptability of the principles of the Grand Antichi project must reach beyond the political or social, and include the producers, if the project is to take hold. This is logical, as the farmers must dedicate a portion of their land and resources. The question of consumer acceptability is variable, as some projects have started with a strong consumer base, and others have yet to create one, but are confident that the 
experience in Montespertoli can be extended to their areas in terms of consumer interest, buy-in and support.

Adoption can be quite limited, as the case of Umbria illustrates. However, adoption is linked to sustainability in each case, as the number of farmers and the amount of grain produced must be absorbed by the local market if the project is to maintain its commitment to a $30 \%$ partition of earnings.

A significant factor in the replication process and the level of success of a project appears to be the level of commitment of the main stakeholder as project driver. Adoption of clear policies is also seen to contribute to success to a lesser degree. The education and motivation of the farmers are fundamental factors as well. Last but not least is the creation of an economic model that includes consumers. Consumers need to be educated that by purchasing products made locally in a sustainable way they are sponsoring cleaner agriculture that improves the soil and redistributes revenues in a fairer, healthier way, which is the base of transformational change.

Based on the results and experiences of this project, the following quantitative indicators that measure the progress of these activities in the aim for transformative change are suggested:

- Total number of projects in biodiverse grains in Italy;

- Number of direct farmers involved in different communes in Italy year to year;

- Number of hectares cultivated through local association activity;

- Number of kilograms of wheat harvested;

- Average price per kilogram of wheat paid to farmers;

- Number of government incentives for cultivating biodiverse wheat;

- Number of city council policies favouring organic agriculture of biodiverse wheat; and

- Number of varieties in national system reporting and registry.

Some of these values are reported in Tables 6.2 and 6.3 in relation to the Montespertoli project, 2013 to 2019. It is expected to provide a comparative base for future analysis and support for not only further scale-out but also scale-up and scale-deep.

\subsection{Final Reflection: Changes in the Community}

Normally people shop looking for what they like at the lowest price. However, the new system described herein requires people to understand that low prices have repercussions up the chain, and local people cannot bear the burden of price instability. Consumers need to step out of market economy rules and adapt to paying prices that reflect the actual cost of the product, knowing that the benefits are equally redistributed along the chain. In this way, consumers become project participants rather than just end users. This involves concerted local communication and social efforts to involve consumers so they see themselves in this new role. It also 
profoundly changes individuals' feelings of responsibility leading to positive action regarding sustainable practices and concrete responses to climate change.

Another significant change was the realisation within the Association that making cultivation of ancient grain wheat attractive through rewarding producers can lead to expectations that these new benefits are guaranteed to the individual in all circumstances. If, as in the case of a limited distribution chain and excess yield, even beyond the Association's mitigation plan of surface and plant allocation, adjustments need to be made, the project risks collapse because of negative feelings among some producers. In 2019 in Montespertoli, benefits could only apply to a few producers with large cultivated surfaces or to many producers, including those with small surfaces. The Montespertoli Association decided to benefit a large number of producers each with small areas, negatively impacting the larger producers who could potentially have sold more.

Replication requires an understanding of the relationship between production and demand, and also consideration of who the main stakeholder is during the implementation of the project, as different stakeholders with different roles will introduce different limitations to the project. For example, in Montespertoli, the first and strongest stakeholder was the miller, and the chain was primarily organised around the quantity of wheat that the mill was able to transform. Recognising this limit, a second mill was introduced thanks to an investment made possible by a grant from the Tuscan region. In some other chains, for example where the initial and strongest stakeholder is a farm using mills as an external resource, the problem is primarily market demand. If, on the other hand, the main stakeholder is a shop, the chain will be created based on its market potential.

To conclude, projects of this kind require consumers to change their purchasing attitudes. They need to become co-producers as project participants and understand the cost and value of agricultural products. In this way, superior products are made available and a socio-ecologically sustainable environment is maintained. The producers as well as the processors need to create a common chain so that they all benefit from consumer awareness.

Ultimately, the biggest goal would be to transform society into groups of people who understand that humans have a responsibility to preserve biodiversity and the environment. Therefore, all fields would be cultivated in a sustainable way, and all bread would be made with wheat made in those fields, as people would not want any other. This goal applies to all other agricultural products as well. The Ancient Grains Association's actions are a concrete response to Goal 12 of the Sustainable Development Goals by the United Nations on Responsible Consumption and Production (Fig. 6.3). 


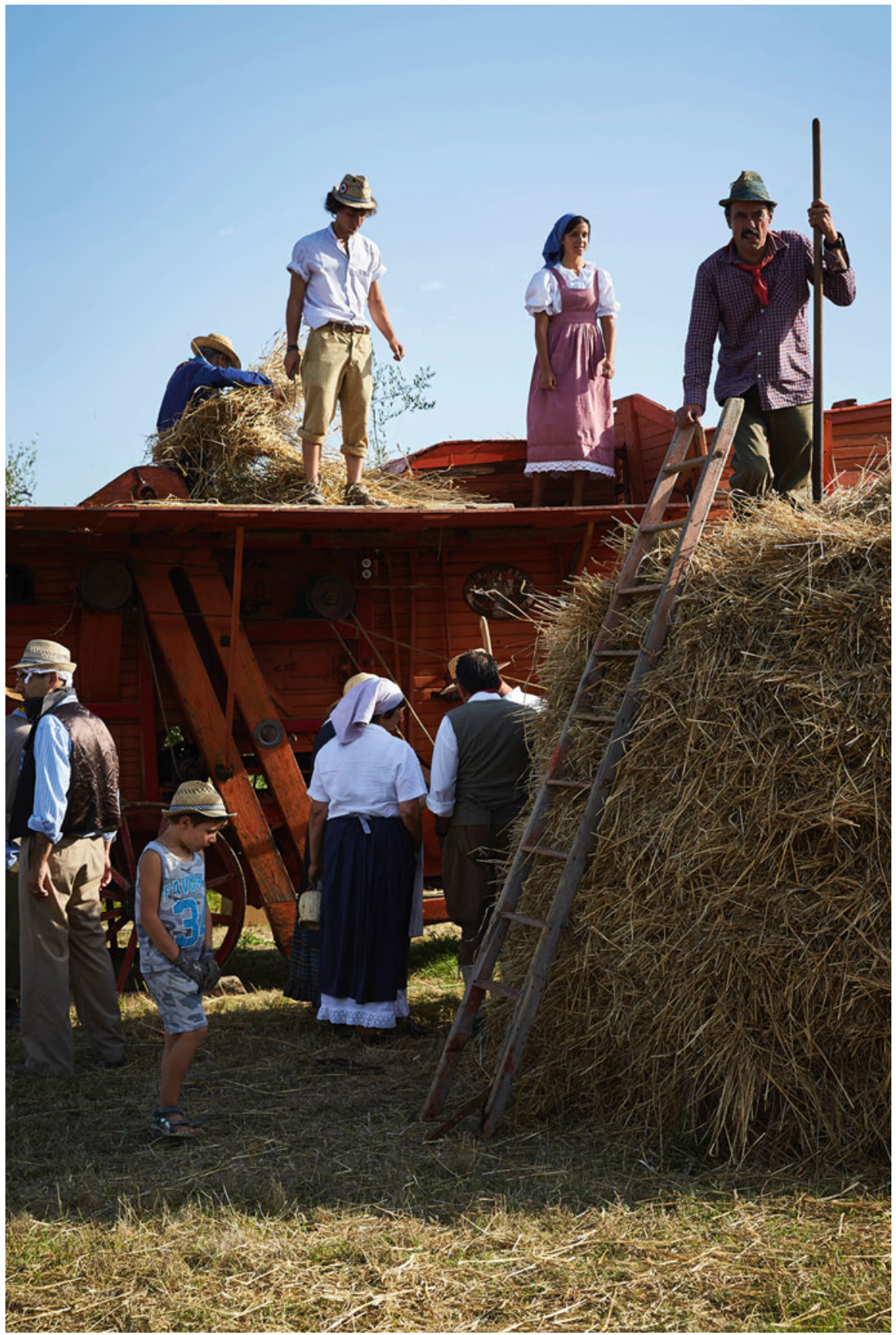

Fig. 6.3 Harvest party (Photo: Batistelli) 


\section{References}

Enghiad, A., Ufer, D., Countryman, A., \& Thilmany, D. (2017). An overview of global wheat market fundamentals in an era of climate concerns. International Journal of Agronomy, 2017, $1-15$.

Sacchi, G., Belletti, G., Biancalani, M., Lombari, G. V., \& Stefani, G. (2019). The valorisation of wheat production through locally-based bread chains: Experiences from Tuscany. Journal of Rural Studies, 71, 23-35.

Sofi, F., Ghiselli, L., Cesari, F., Gori, A. M., Mannini, L., Casini, A., Vazzana, C., Vecchio, V., Gensini, G. F., Abbate, R., \& Benedettelli, S. (2010). Effects of short-term consumption of bread obtained by an old Italian grain variety on lipid, inflammatory and hemorheological variables: an intervention study. Journal of Medicinal Food, 13, 1-6.

The opinions expressed in this chapter are those of the author(s) and do not necessarily reflect the views of UNU-IAS, its Board of Directors, or the countries they represent.

Open Access This chapter is licenced under the terms of the Creative Commons Attribution 3.0 IGO Licence (https://creativecommons.org/licenses/by/3.0/igo/), which permits use, sharing, adaptation, distribution and reproduction in any medium or format, as long as you give appropriate credit to UNU-IAS, provide a link to the Creative Commons licence and indicate if changes were made.

The use of the UNU-IAS name and logo, shall be subject to a separate written licence agreement between UNU-IAS and the user and is not authorised as part of this CC BY 3.0 IGO licence. Note that the link provided above includes additional terms and conditions of the licence.

The images or other third party material in this chapter are included in the chapter's Creative Commons licence, unless indicated otherwise in a credit line to the material. If material is not included in the chapter's Creative Commons licence and your intended use is not permitted by statutory regulation, or exceeds the permitted use, you will need to obtain permission directly from the copyright holder. 